\title{
An Archaeochemical Microstructural Study on Koryŏ Inlaid Celadon
}

\author{
Seung Wook Ham, Il-wun Shim, Young Eun Lee, Ji Yoon Kang, and Kỵongshin Koh \\ Department of 'hemistry, ('hang-Ang Thiversit, Seoul 156-756, Korea \\ Received Hoy 21, 2002
}

\begin{abstract}
With the invention of the inlaving technique for celadon in the latter half of the 12 th century, the Koryo potters reached a new height of artistic and scientific achievement in ceramics chenical technology. Inlaid celadon shards, collected in 1991 during the surface investigation of Kangjin kilns found on the solthwestem shore of South Korea, were inbedded in epory resin and polished for cross-section examination. Backscattered electron images were taken with an electron microprobe equipped with an energy dispersive spectroneter. The spectrometer was also used to determine the composition of micro-areas. Porcelain stone, weathered rock of quartz, nica, and feldspar composition were found to be the raw material for the body and inportant conponents in the glaze and white inlay. The close similarity between glaze and black inlay in the microstructure suggests that the glaze material was moditied by adding clay with high iron content, such as biotite, for use as black inlay. The deep soft translucent quality of celadon glaze is brought about by its microstructure of bubbles, remnant and devitrified minerals. and the schlieren effect.
\end{abstract}

Key Words : Microstructure, White inlay, Tlack inlay, Koryŏ inlaid celadon, Korcan traditional ceramics

\section{Introduction}

Some of the world's most coveled and admired masterpieces of ceranics art were produced in Korea during the Kory̆ and Chosŏn dy̆nastics. They were the result of highly sophisticated technology that was basically chemical in nature. The ability and skill to select and treat materials for body. glaze. and decorative propertics. to attain the high temperature necessary for proper vitrification of stoncware and porcelain. and to control the atmosplice in the kiln for developing desired glaze colors made ceramics teclunology the premicr high teclinology of that time. Korca and China were the only countries that possessed such an advanced chemical technology as carly as the ninth century.

Ceramic products are highly complicated multicomponent heicrogencous systems that have been the subject of intense chemical rescarch for centurics. The rescarch began in camest several decades before the Chemical Revolution when Italians. Genmans. French and the English raced to producc hard-paste white porcelain. "white gold". imported from China. Rene de Reaumur. Jean Hellot. and Picre Joseph Macquer were among numerous clicmists who were instrumental in applying successfully chemical principles to ceramics production.'

The science of Korcan stoncware and porcelain is just beginning to be unfolded. Unlike their Chinese countepparts. Korcan stoncware first became the subject of analysis in the 1970's. acijely only in the las1 decade ${ }^{-6}$ Though late in arrival by several centuries. the current interest in Korcan ccramics boll as art and science nuns decp and wide. Also. modem soplisticated instruments and techniques are cnabling these objects to reveal themselyes in detail as never before.

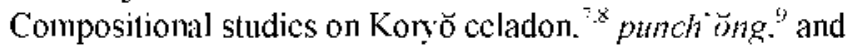
Chosón whiteware Recently a microstructural study on punch ong was present- cd." and in this paper a microstructural image and connpositional analysis with EPMA (clcctron probe microanalyzer) on the inlaid celadon from Kangjin is presented. In Kangjin. in the southwestern tip of South Korca. the inlay technique was invented and blossomed into Koryŏ masicrpicces.

Inlaying technique is the sccond of wo original aclicicments and an cxtension of the first Kory̆ŏ potters in Kangjin made in the cleventh and twelfth centuries. Their first achicvement of jade-like pisoek glaze produced celadon masierpices that were already recognized as the first under leaven. ${ }^{12}$ On many of the picces were incised such figures as lolus buds and peony flowers. which showed through the clear bluc-grecn glaze. In inlay decorative tecliniques the incised lines and planes were filled with white or black clay matcrial to contrast with the gray body color. With this sccond invention the craftsmen creativity reached a new height producing such famous picces as the meipyong. uniquely decorated with flying cranes and clouds. In Figure (a) is shown another popular type of celadon. a vase with chrysanthemum flowers in while and black inlay. Later in the fourtecnth century several modifications in the incision and filling techniques led to anolher unique Korean ceramic art punch ong. The usc of only simple carthy material mather than colorful overglaze pigments is apprecialed today as quintessentially oriental.

\section{Experimental Section}

Inlay celadons were produced mosily in Sadangni kilns in Kangjin during the $13^{\text {th }}$ and $14^{\text {th }}$ centuries. The kilns were investigated in depth in 1991 by a team from Hacgang Ceramics Muscum. who provided the ceramic shards for this analysis. Typical slards used in the study are shown in Figure 1(b).

The shards were cmbedded in epoxy resin and polished for 


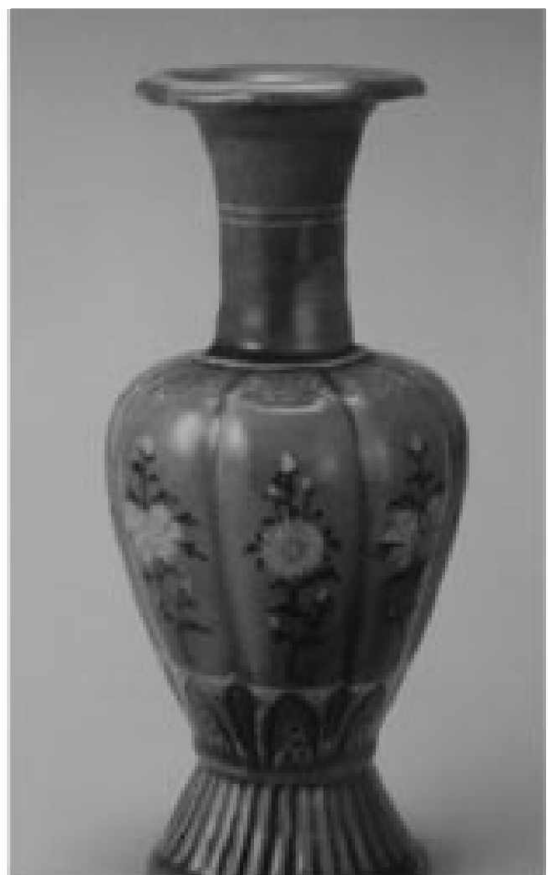

(a)

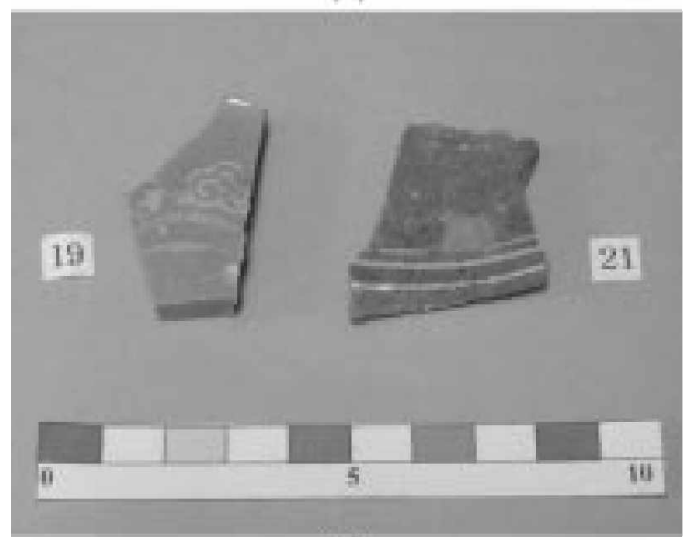

【b]

Figure 1. Tnlaid celadon produced in the latter halt of Korr drinasty (a) A vase decorated with white and black inlay: (b) Typiwal shards from Kangjin kiln that were antyzed in this study lor the microstructural characteristics.

cross-section examination. The BEl (backscattered electron images) and detemination of the composition of micro-areas were made at Hoffman Geological Laboratory of Harvard University on a Cameca $\mathrm{MBX}$ electron nicroprobe equipped with a Tracor Northern TN-5502 Energy Dispersive Spectrometer and a stage automation system. The geological standard. detection limit. and counting error used for each element were as follows: for Si quartz, 0.04 wt. $\%$ and 0.30 $\%$; for $\mathrm{Al}$ anorthite. 0.03 wt. \%, and $0.15-0.30 \%$, for $\mathrm{Fe}$ hematite. $0.06 \mathrm{wt} \%$. and $0.04-0.07 \%$, for $\mathrm{Mg}$ enstatite. 0.02 wt. $\%$. and $0.02 \%$, for Ca anorthite, $0.04 \mathrm{wt} \%$. and $0.05-$ $0.16 \%$, for Na albite. 0.03 wt. \% and $0.05 \%$, for $\mathrm{K}$ microcline. $0.03 w \mathrm{w} \%$, and $0.0+-0.10 \%$, for Ti rutile. $0.08 \mathrm{wt} \%$. and $0.20-0.40 \%$, for $\mathrm{Mn}$ tephroite. $0.05 w \mathrm{w} \%$, and $0.02 \%$, for $\mathrm{P}$ apatite. $0.0+w \mathrm{w} . \%$ and $0.03 \%$. Bence-Albee 85 and Amstrong alpha values were used for matrix correction. Beam energy

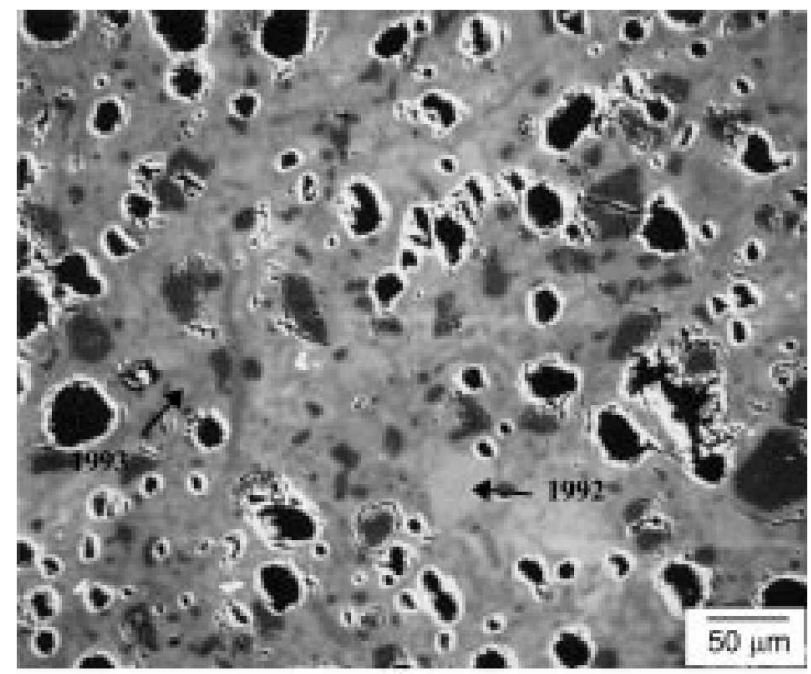

(a)

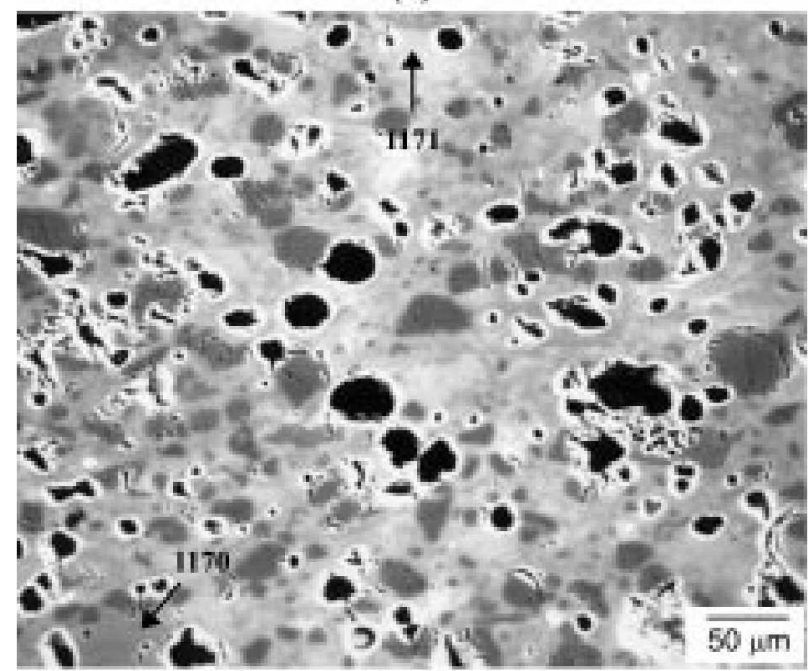

(b)

Figure 2. Backscaltered electron images (BLI) of hodf. (a) Shard sample 22 (CLil 1-3): (b) 169 (\$-27-9).

was $15 \mathrm{keV}$ and beam current. $1+\mathrm{nA}$. Various beam sizes of 3. 6 . and $15 \mu \mathrm{m}$ and in some cases a point beam were used for measuring microstructural composition.

\section{Results and Discussion}

Body. Hard-paste porcelain material is basically composed of three materials, each providing different properties: clay with plasticity; feldspar that facilitates melting and mixing of different mineral components, and refractory quartz. which prevents collapsing of shaped wares from over-melting. The plasticity necessary for forming is provided. as expected. by kaolinite and other similarly structured clay minerals in raw ceramic materials from the loess plains of northem China and in various western fonmulations for the body ingredients. However, the plastic component in tosuk (pottery stone or porcelain stone), the naturally occuming weathered rocks from which the oventhelming majority of Korean stoneware and porcelain and those from southern China are produced is mineral with mica structure in various forms. such as musco- 
Table 1. Composition of micro-areas in body measured by FPMA

\begin{tabular}{|c|c|c|c|c|c|c|c|c|c|c|c|c|c|}
\hline \multirow{2}{*}{ Plase } & \multirow{2}{*}{ Sample no. } & \multirow{2}{*}{$\begin{array}{c}\text { Analyzed } \\
\text { point }\end{array}$} & \multicolumn{11}{|c|}{ Normalized oxide conectitration (wt. ${ }^{0}{ }_{0}$ ) } \\
\hline & & & $\mathrm{SiO}$ & $\mathrm{Al}_{2} \mathrm{O} \mathrm{S}_{\mathrm{S}}$ & $\mathrm{lie} 2 \mathrm{O}_{3}$ & $\mathrm{MgO}$ & $\mathrm{CaO}$ & $\mathrm{Na}$ & $\mathrm{K}_{2} \mathrm{O}$ & $\mathrm{TiO}_{2}$ & $\mathrm{MnO}$ & $P_{2}()_{5}$ & $\mathrm{SO}_{3}$ \\
\hline \multicolumn{14}{|l|}{ body } \\
\hline manix $I$ & $22(\mathrm{Cl} i]]-3)$ & 1193 & 56.85 & 35.33 & 2.76 & 0.79 & 0.44 & 0.78 & 2.44 & 0.5 .3 & 0.03 & 0.0 .3 & 0.02 \\
\hline$(\Lambda)$-ricls silicate: & $166(\mathrm{~S}-27-6)$ & 1161 & 58.92 & 32.26 & 2.73 & 0.86 & 0.27 & 1.01 & 3.40 & 0.42 & 0.04 & 0.0 .3 & - \\
\hline muscovite) & ] $69(S-27-9)$ & 1170 & 54.20 & 40.68 & 1.38 & 0.42 & 0.22 & 0.52 & 2.41 & 0.12 & 0.02 & 0.02 & - \\
\hline matrix 2 & $22(\mathrm{Cl} i]]-3)$ & 1192 & $68 . \mathrm{km}$ & 18.76 & 5.10 & 1.28 & 1.22 & 1.51 & 3.86 & 0.19 & 0.04 & 0.0 .3 & - \\
\hline (K-rich silicule: & $166(\mathrm{~S}-27-6)$ & $1] 59$ & 67.93 & 19.31 & 2.81 & 0.76 & 0.82 & 2.23 & 6.06 & 0.04 & 0.03 & 0.01 & - \\
\hline \multirow[t]{2}{*}{ K-(e)/dspar) } & & $1] 60$ & 68.58 & 18.91 & 4.53 & 1.33 & 0.50 & 1.32 & 4.67 & 0.12 & 0.03 & - & - \\
\hline & ] $69(S-27-9)$ & 1171 & 66.115 & 23.15 & 3.46 & 1.12 & 0.56 & 1.07 & 4.10 & 0.36 & 0.09 & 0.0 .3 & - \\
\hline \multicolumn{14}{|l|}{ glaze } \\
\hline K-feldspar nelict & ] $66(S-27-6)$ & 1145 & 65.85 & 16.19 & 0.65 & 0.48 & 9.31 & 1.11 & 6.22 & 0.00 & 0.18 & 0.01 & - \\
\hline $\begin{array}{l}\text { (within the aggregation } \\
\text { of quart/ grains) }\end{array}$ & & 1148 & 66.86 & 14.87 & 0.40 & 0.61 & 10.50 & 0.94 & 5.40 & 0.00 & 0.20 & 0.21 & - \\
\hline "ollastomite & $166(S-27-6)$ & 1114 & 51.41 & 0.10 & 0.08 & 0.114 & 47.99 & 0.01 & 0.10 & 0.00 & 0.09 & 0.18 & - \\
\hline \multirow[t]{2}{*}{ muscowite relict } & ] $69(S-27-9)$ & ]168(core) & $5(1.59$ & 39.66 & 0.18 & 0.14 & $3(1) 0$ & 0.80 & 5.52 & 0.04 & 0.04 & 0.0 .3 & - \\
\hline & & $1] 69($ rim $)$ & 50.10 & 30.71 & 0.24 & 0.28 & 16.115 & 0.98 & 1.26 & 0.02 & 0.06 & 0.30 & - \\
\hline schlieren effect & $22(\mathrm{Cl} i]]-3)$ & 1187 & 57.76 & 12.76 & 1.77 & 2.00 & 21.67 & 0.26 & 2.64 & 0.00 & 0.42 & 0.71 & - \\
\hline \multirow[t]{2}{*}{ light } & & 1188 & 54.83 & 1.3 .49 & 2.00 & 2.24 & 23.77 & 0.31 & 1.82 & 0.00 & 0.54 & 1.01 & - \\
\hline & & 1191 & 56.27 & $1.3(t) 1$ & 1.73 & 2.22 & 22.57 & 0.31 & 2.25 & 0.15 & 0.48 & 0.98 & 0.02 \\
\hline \multirow[t]{2}{*}{ dark } & & 1189 & 59.54 & 1.3 .25 & 1.41 & 1.73 & 19.33 & 0.34 & 3.34 & 0.00 & 0.36 & 0.68 & - \\
\hline & & 1190 & 56.88 & 1.3 .53 & 1.94 & 2.01 & 21.40 & 0.33 & 2.32 & 0.18 & $(1.49$ & 0.90 & 0.02 \\
\hline \multicolumn{14}{|l|}{ white inlay } \\
\hline \multirow[t]{3}{*}{ whiscovife retict } & $166(S-27-6)$ & 1157 & 52.25 & 39. 44 & 2.80 & 0.73 & 0.17 & 0.62 & 3.86 & 0.06 & 0.02 & 0.05 & \\
\hline & & 1158 & $50.00)$ & 3.3 .30 & 6.77 & 3.49 & 0.19 & 0.77 & 5.39 & - & 0.09 & 0.01 & - \\
\hline & $\left.\left.1333 b(I) l^{\prime}\right] 2-2\right)$ & 1197 & 51.27 & 39.59 & 0.97 & 0.31 & 0.88 & 0.12 & 6.28 & 0.02 & 0.06 & 0.31 & 0.18 \\
\hline contparisot of & $19(\mathrm{Cll}]-2)$ & white inlay & 59.50 & 34.40 & 1.22 & 0.33 & 0.55 & 0.27 & 3.34 & 0.08 & 0.03 & 0.07 & 0.20 \\
\hline infergede with & white 4 & glaze & 59.188 & 1.3 .51 & 1.34 & 2.27 & 19.51 & 0.39 & 2.53 & 0.12 & 0.41 & 0.82 & \\
\hline inflay affd glaze? & & intergrade & 61.44 & 17.85 & 1.75 & 1.73 & 12.48 & 0.38 & 3.48 & 0.12 & 0.31 & 0.47 & 0.01 \\
\hline apatife & $22(\mathrm{Cl} i] 1-3)$ & 1185 & 14.88 & 2.70 & 0.85 & 0.71 & 49.79 & 0.09 & 0.16 & - & 0.30 & 30.51 & - \\
\hline \multicolumn{14}{|l|}{ black inlay } \\
\hline \multirow[t]{2}{*}{ matrit } & $166(S-27-6)$ & 1166 & 51.98 & 22.20 & 12.63 & 2.50 & 6.21 & 0.78 & 2.07 & 1.015 & 0.25 & $0 . .31$ & - \\
\hline & & 1167 & 55.28 & 19.70 & 12.06 & 2.40 & 5.47 & 0.83 & 2.60 & 0.74 & 0.22 & 0.71 & - \\
\hline atrorthite & $169(S-27-9)$ & 1165 & 47.7 .3 & 32.72 & 0.63 & 0.15 & 17.1 .3 & 0.85 & 0.41 & 0.10 & 0.04 & 0.23 & - \\
\hline \multirow{2}{*}{ spithel } & $22(\mathrm{Cl} 111-3)$ & 1172 & 4.26 & 56.66 & $.30) .44$ & 7.40 & 0.27 & 0.03 & 0.28 & 0.36 & 0.23 & 0.04 & 0.03 \\
\hline & & 1173 & 2.18 & 58.87 & 300.45 & 7.77 & 0.1 .3 & 0.02 & 0.11 & 0.23 & 0.20 & 0.012 & 0.01 \\
\hline spinel & $160,(S-27-6)$ & 1151 & 1.61 & 58.13 & 33.34 & 6.61 & 0.08 & - & 0.11 & - & 0.11 & - & - \\
\hline
\end{tabular}

vite. biolite. sericite and illite.

These various muscovitc-lype minerals are formed as imtenmediary mincrals in granite rocks whose Na-and K-rich feldspars are transformed to clays of aluminous silicates wilhoul ary alkaline clements. Various amounts of $\mathrm{Na}$ and $\mathrm{K}$ remaining in these intenncdiary mincrals act as flux. while the extreme fineness of the grains and their platy claracteristics make them plastic. Feldspars that remain unclanged facilitate the fluxing. while a small amount of the clay end product provides further plasticity. Quarty is abundantly prescml in thesc granite rocks in all stages of transfonnation. Tlus tosuk contains all the necessary ingredicnts in its natural state for stoncwarc and porcelain. allowing Korcan and soulhern Chinese potters to make their wares tammi. singletaste. with this carthen material alone. only after refining it through the mechanical steps of pounding. floating. and kncading.
Two images of body in Figure 2 show the microsinuctural characteristics of inlaid celadon that was made with tosuk. Most of the original mincrals and pores have disappeared in the process of vitrification and densification. Unlike for glass. the firing is slopped before the ceramics bodies are fully and homogencously vitrified. and the microstructural features were "frozen-in" when the heating is stopped.

The matrix consists of two irregularly mixed glassy phases. which reflect the composition of the original mincrals. As shown in Table 1 the lighter plase. represented by the points 1171 and 1192. is rich in potassium and low in aluminum oxide. as its main component was feldspars. especially of $\mathrm{K}$ type (microcline or orthoclase). The darker plase. represented by the points 1170 and 1193. is derived from high aluminum muscovite minerals.

The darkest (black) irregularly shaped hollow sites are the pores. much fewer in number and mome round than the pores 


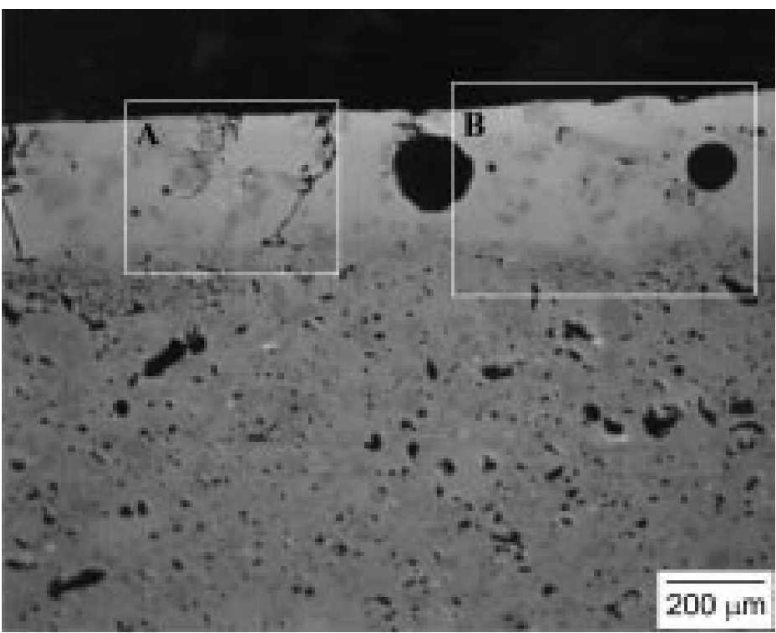

['由]

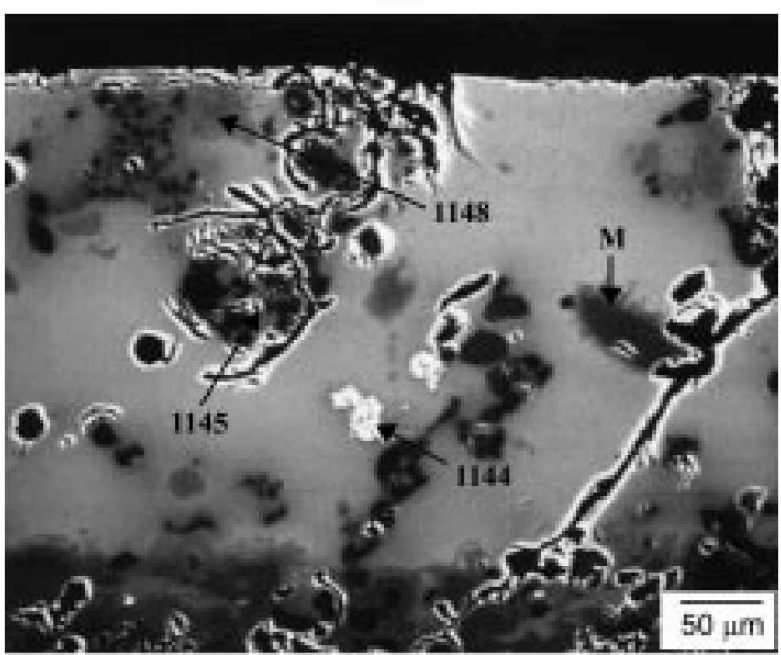

(b)

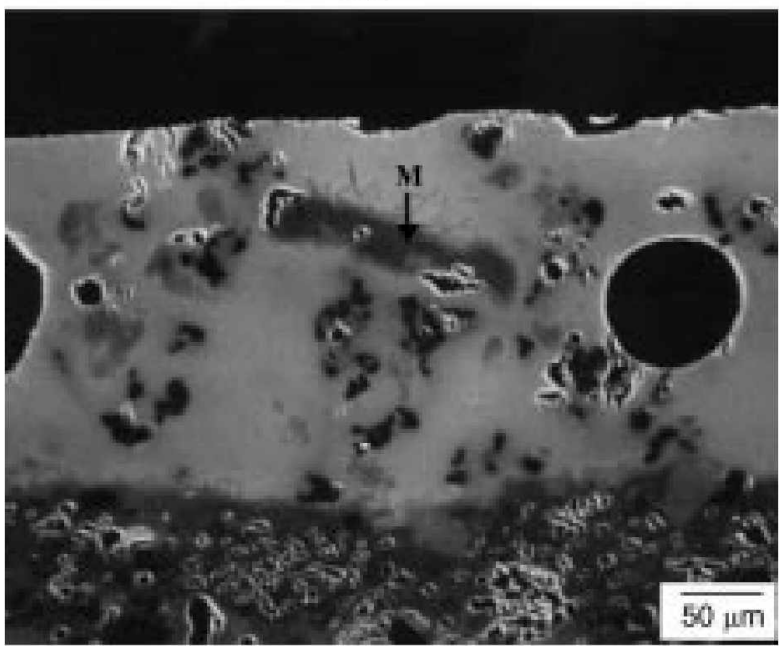

(c)

Figure 3. Backiscatlered electron images of the sample 166 (S-276). (a) Body and glaze: (b) $A$ higher magnification of area $A$; (c) $A$ ligher magnification of area $B$.

present in raw material before the firing. The dark gray grains are quarl $\%$ most of which retained their shape. Some lave crackled. especially around the edges during the cooling pro- cess. Mullite both primañ and sccondañ formed from highalıminum mineral and feldspar, respectively, when the wares are fired above $1050^{\circ} \mathrm{C}$. is not shown in these images. Usually too fine and small to be secn in electron images. their peaks occur prominently along with those of quarty in $\mathrm{X}$-ray diffraction patterns of the fully fired bodics.

Glaze. The glave is much further yitrified than the bodies duc to the higher content of flux, provided chiclly by $\mathrm{CaO}$. Some highly fluxed glares are completely vitrificd appearing clear and transparent as glass. Some contain mincral grains that have been dissolved only partially or exen not at all during the firing process and some that have devitrified newly during the cooling process. Most contain bubbles of rañing size and quantity. They are pockets of gases. which fonned and flowed toward the surface during the vitrification process and were trapped when the firing was stopped.

The glare on inlaid celadon usually contains bubbles and both remuant and devitrificd mincrals. In fact. the characteristic translucent quality of celadon glaze comes from this microstnucture of bubbles and mineral grains. which scatter and diffract light. The glaze of the shard 166 (S-27-6) shown in Figure 3 is an cxample of ccladon glare that has sereral variclics of much relicl and deritrified minemals. Figure $3(a)$ of the image magnified only by aboul 70 times shows the overall difference betwecn the body and glaze microstricture. Relatively large and also tiny bubbles occur in the glare. while many pores of various size and shape are in the body. Dark thin lines that go through the entire glare shown on the left cdge and also on the right borderline of the area boxed as $\mathrm{A}$ are the image of crackles that are found often in glazes of ccladon and other traditional stoncware and porcelain.

The higher magnifications of area $\mathrm{A}$ in Figure $3(\mathrm{~b})$ and of arca $B$ in Figure $3(\mathrm{c})$ make the identification of the mincals possible. In the upper middle section in Figure $3(\mathrm{~b})$ is a large partially dissolyed grain whose edge is cracked. Actually it consists of two different compositions. one that appears slightly darker than the light gray of matrix and the other is black. The black is the quarty grains. and the lighter arcas. represented here by spot 1145 and 1148 nearby left. show a composition typical of K-rich feldspar (Table 1). Such aggregates of quarl\% and feldspar (granophyycic intergrowth) occur in almosi all glazes of inlaid ccladon from Kangjir. More dramatic images are presented in Figure $4(a-1)$ and Figure $4(\mathrm{a}-2)$ of the shard 172 (S-14-1) whose glare appears much more vitrificd and clearer than that of the shard 166 (S-27-6) in Figure 3. The magnificd image in Figure 4(a-2) slows such clusters of inicrgrowth around and cren underneath the large bubble. Here it is shown clearly that the areas of feldpars melted. while the refractory quarizites remained almost intact during the firing.

The white grains in Figure 3(b) are detennined to be wollastonite ( $\mathrm{CaSiO}_{3} .11+4$ in Table 1). In Chinese celadon these minerals. devitrified during the cooling process. are found rather abundantly. but it is rarely obseryed in Korcan celadon glare. ${ }^{13}$ The lack of this mineral could be an indication that cooling took place more quickly in Kangjin kilns. usually smaller than Clinesc oncs. 


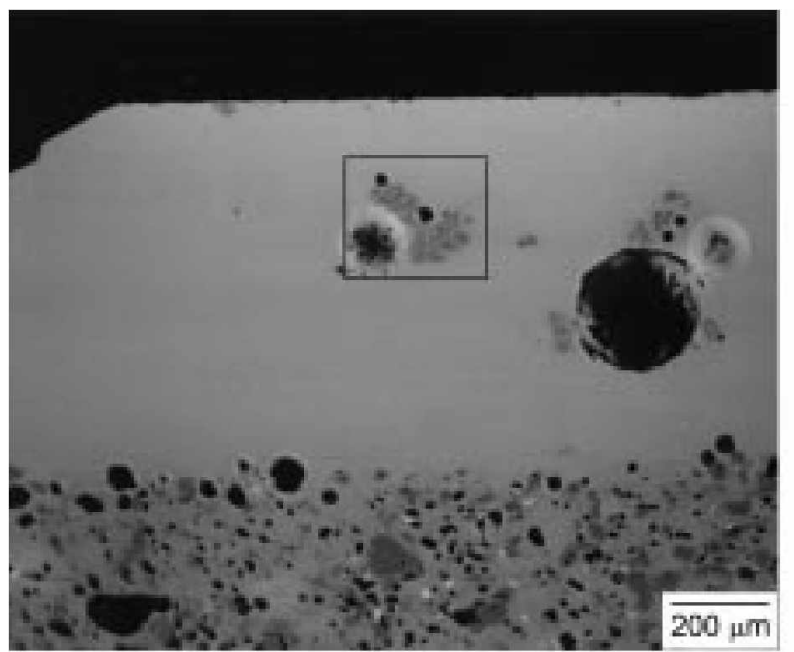

$(a-1)$

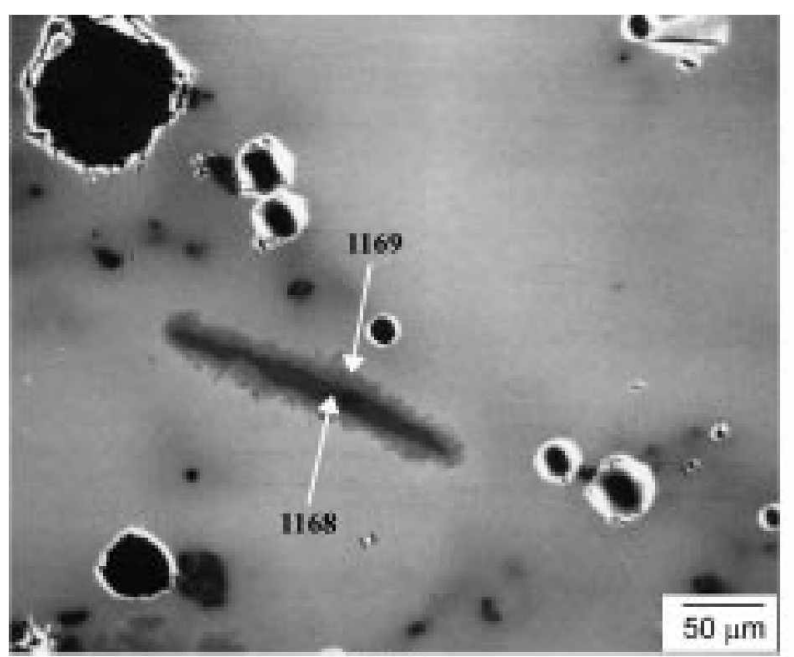

(b-1)

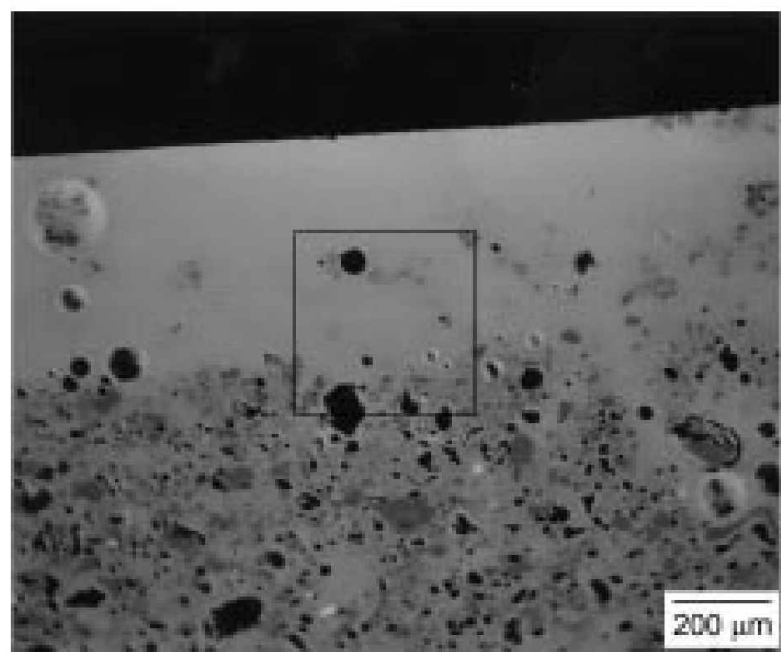

(- 11

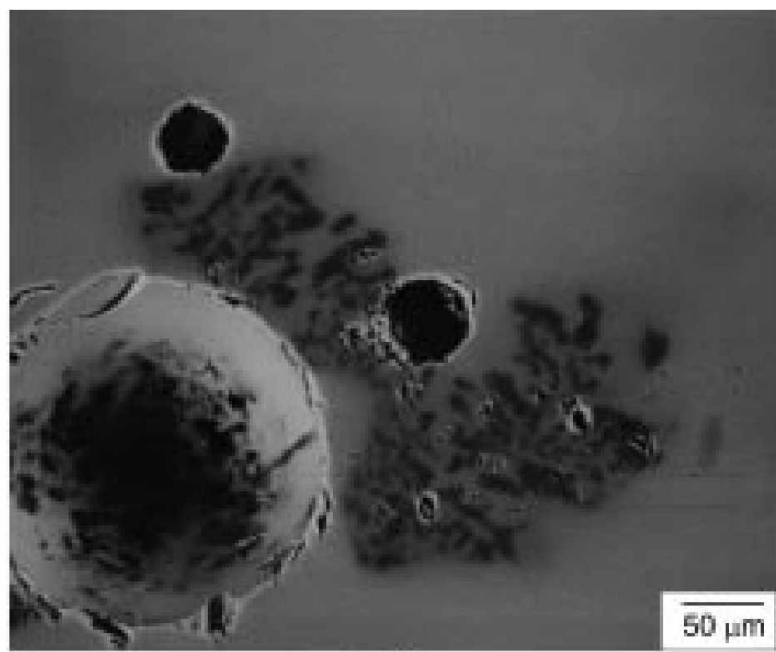

$(\mathrm{B}-2)$

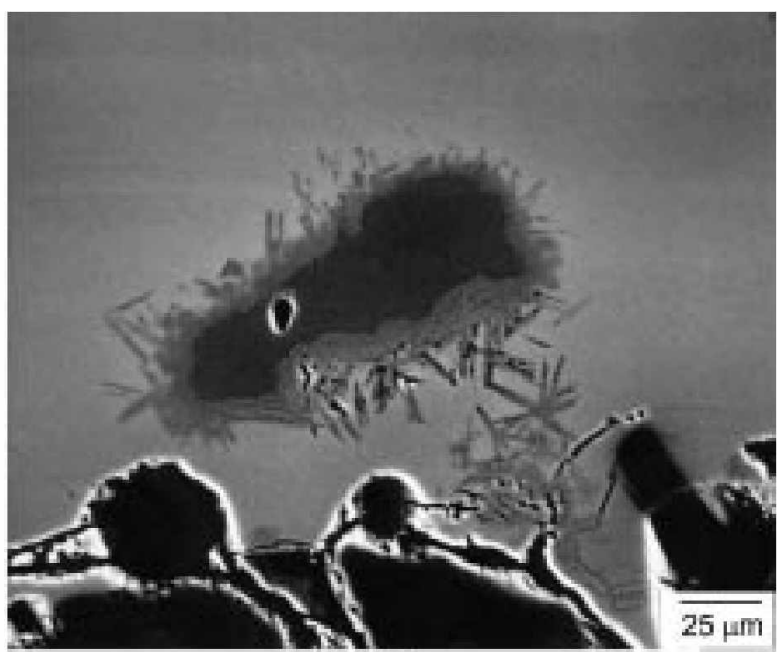

(b-2)

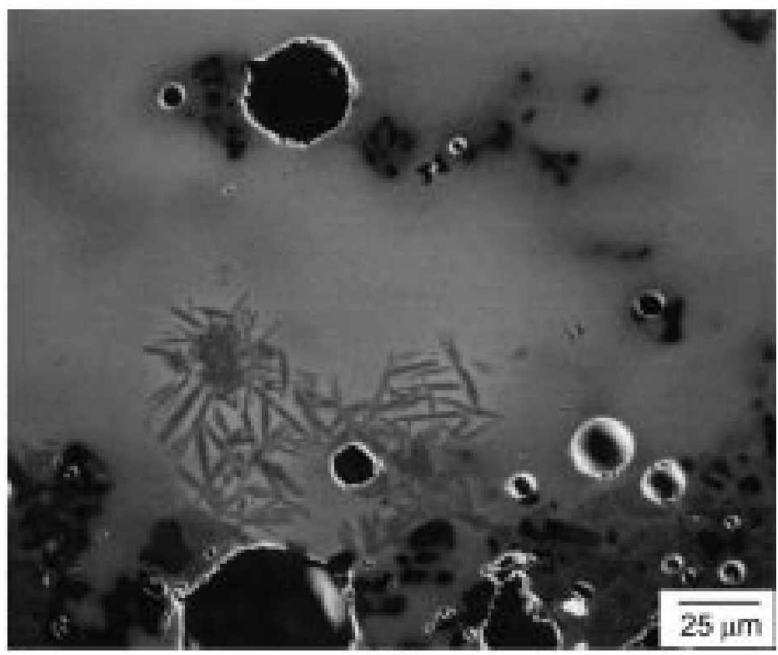

$\{-2\}$

Figure 4 . Backscattered electron images of fone quartz. grains and other crystals in the glaze and the intertace. (al-1) 172 (S-14-1): (a-2) $\wedge$ lijgher magnification of the boxed area in (a-1) (b-1) 169 (S-27-9): (b-2) 171(S-14-1): (c-1) 174(S-10-4): (c-2) A higher magnilication of the boxad area in (c-1). 
In Figure 3(b) is yet another remnant mineral pointed out here by the letier $M$ next to the crackle on the right-hand side and also in Figure 3(c). This clongated mineral occurs often in Kangjin glaze, as shown additionally in Figure $+(b-1)$ and Figure $+(b-2)$. Usually the rim of this relict mineral is dissolved and with the matrix material a new mineral of necdle shape is devitrified. Its EPMA measurement shows that the point 1168 in the core has the muscovite composition $\left[\mathrm{KAl}_{2}\right.$

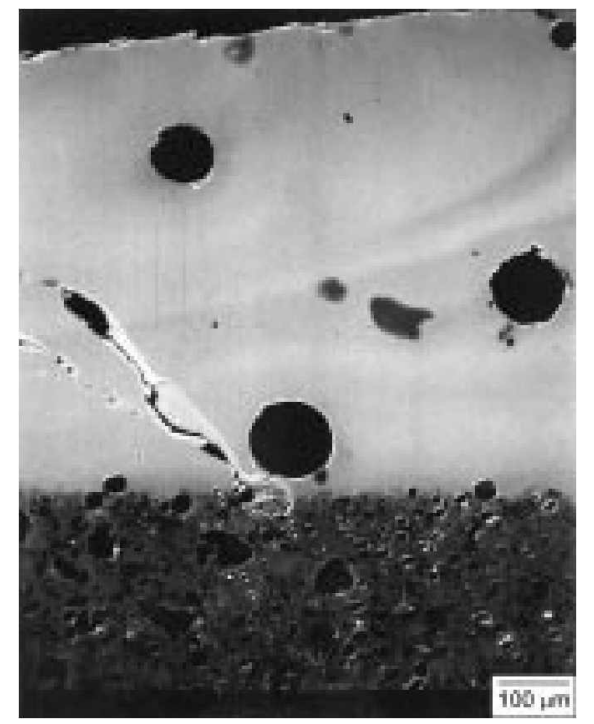

Figure 5. Backscattered electron image of schlieren eftect, an occumence of dark and light contrasting areas, caused by inhomogeneousness of glace composition in shard 22 (CLil l-3).

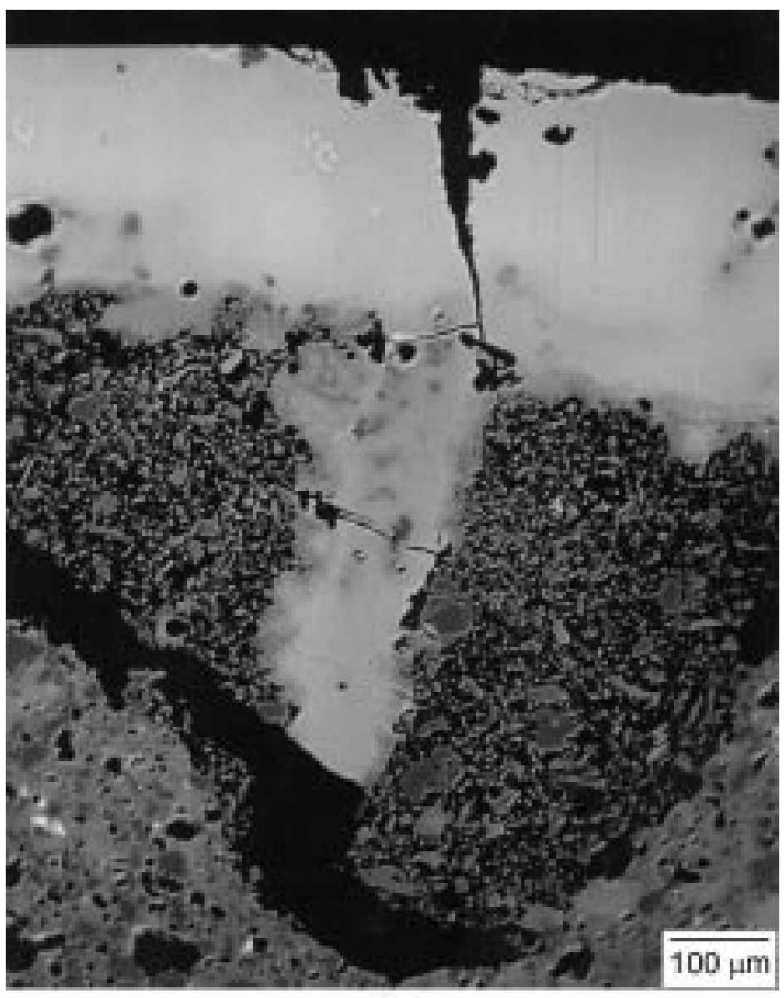

(a)

Figure 6. Backscattered electron mages of white inlay in relation to glaze and bodr (a) 1 ) (CIII-2) (b) 22 (CF.11-3) (c) 166 (S-27-6).
$\left.\left(\mathrm{AlSi}_{3} \mathrm{O}_{11}(\mathrm{OH})_{2}\right)\right]$ of high aluminum and potassium oxides. and the point 1169 on the rim of the needle-shaped mineral has composition close to that of anorthite $\left(\mathrm{CaAl}_{2} \mathrm{Si}_{2} \mathrm{O}_{*}\right)$.

Ca-rich feldspar anorthite is fonned when high $\mathrm{Ca}$ area comes into contact with high aluminum area. as is the case above between the muscovite and glaze. Thus. often this mineral devitrifies along the gla $/ e$ interface with body or white inlay, In Figures 3(b). 3(c), and $+(c-1)$ the presence of this mineral is only suggested along the glazc-body interface.

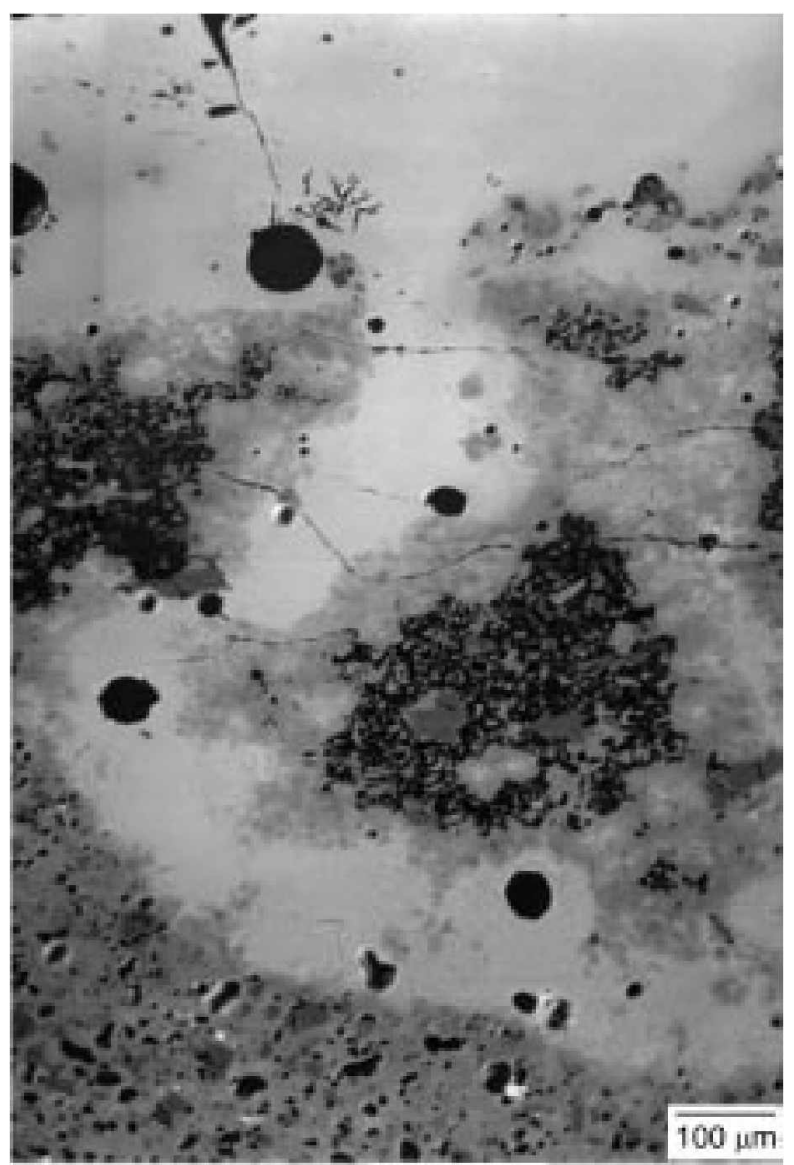

(b)

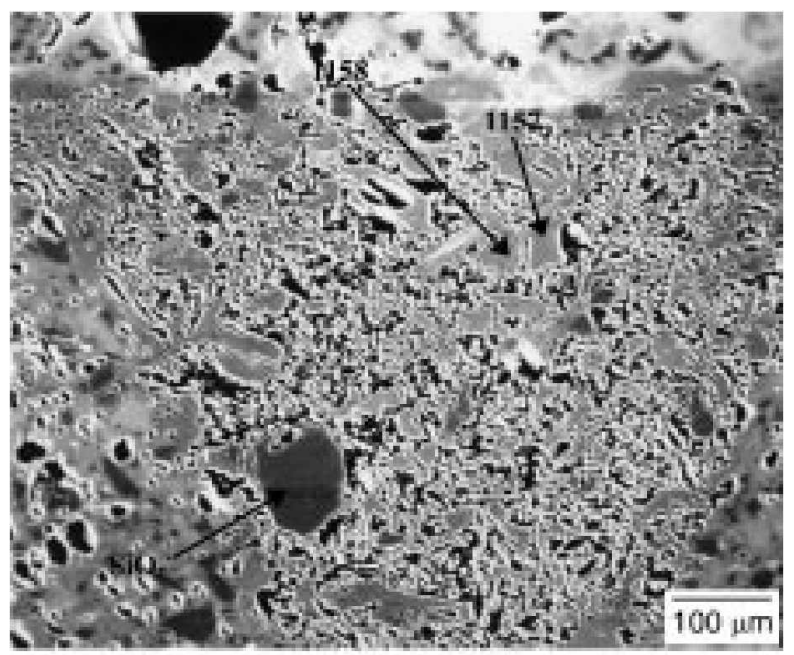

(c)

Figure 6. Continuled. 
but in the more magnified picture of Figure $+(c-2)$ the anorthite necdles are clearly observed near the interface along with small bubbles and aggregates of quart/ites.

Another characteristic that slands out in the ccladon glaze is the schlieren effect. which results from inhomogencous slate of the glaze mixture. Slight differences in composition are manifested as dark ([rom arcas with lighter elements) and light sirips (from arcas with heavier elements), creating wave image in BEl in Figure 5. If glaze were fired longer. small heterogeneities would have resulted in homogeneous glass matrix. A somewhat short firing sclicdule and inadequate mising are likely to have been deliberately chosen to create such a ripple effect. which in combination with various mineral grains and bubbles interacts with light resulting in depth and rich testure.

White Inlay. Three pictures in Figure 6 show the overall

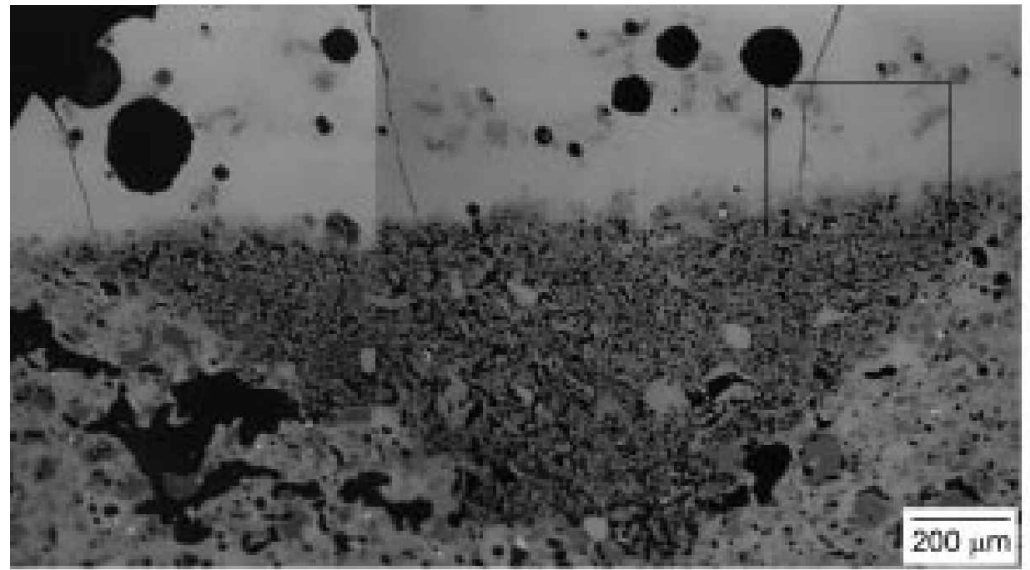

$(a-1)$

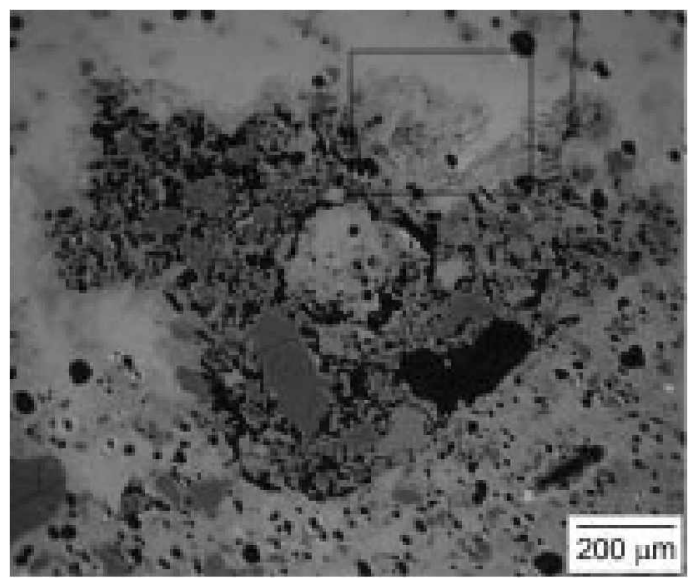

(b-1)

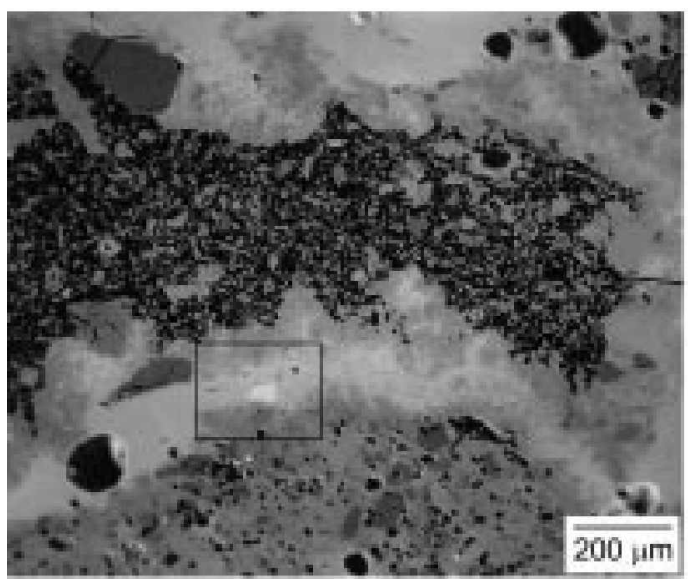

(c-1)

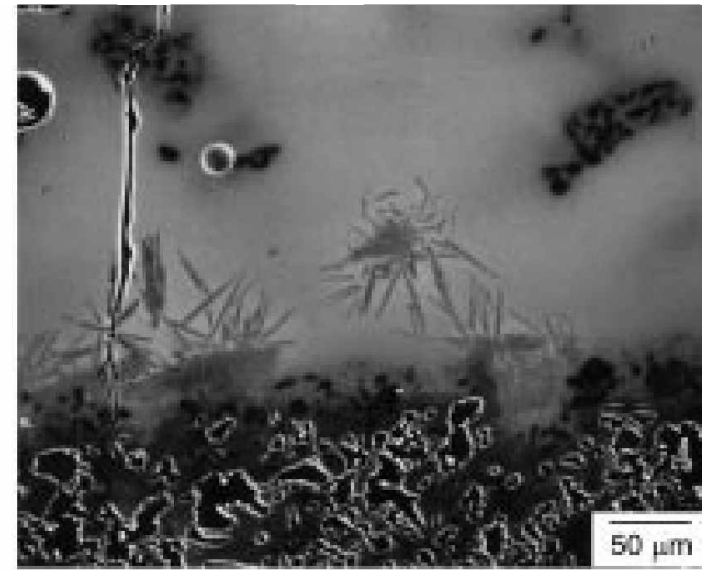

(a-2)

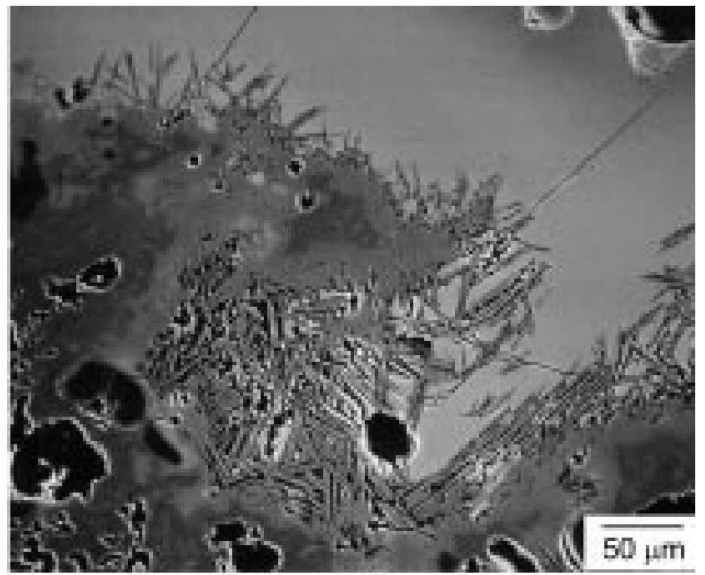

(b-2)

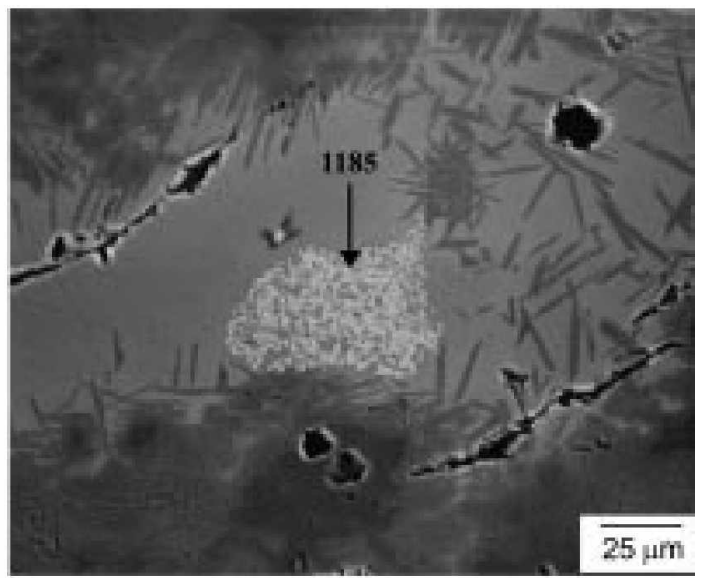

(c-2)

Figure 7. Backscattered electron indages of fine crestals in white inlay and in the intertace between glaze and white inlas: (a-1) 174 (S-10-4): (a-2) A higher magnification of the boxed area in (a-1): (b-1) 171 (S-14-1): (b-2) A higher macnification of the boved area in (b-1): (c-1) 22 (CL1 1-3): (c-2) A higher magnification of the boxed area in (c-1). 
slruclural relationship of the white inlay with the glaze and the body. Most of the inlay is triangular as secn in these piclures. but some are labular line. nunning parallel to the glazc. The shards in Figures 6(a) and (b) are ty pically vitrified. while Figure $6(c)$ shard is substantially under-fired. The inlay is usually cven less vitrified than body due to its high

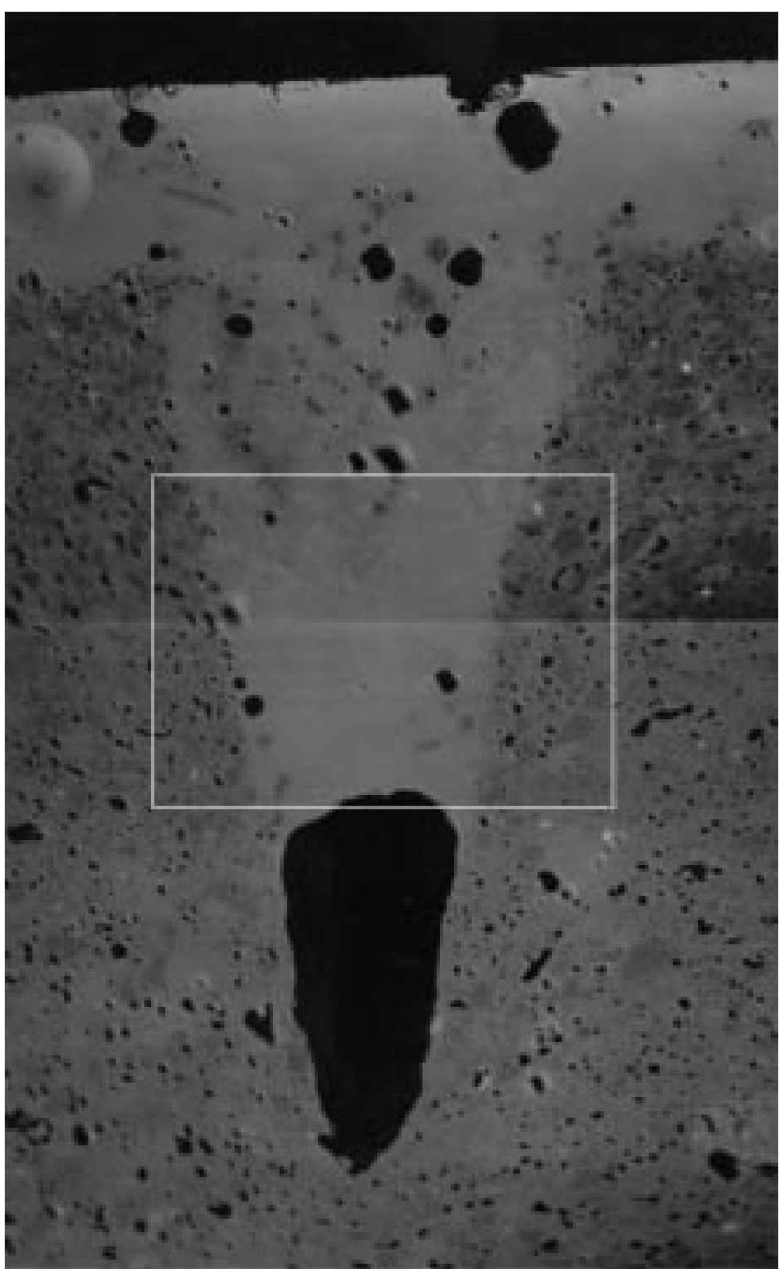

(a)

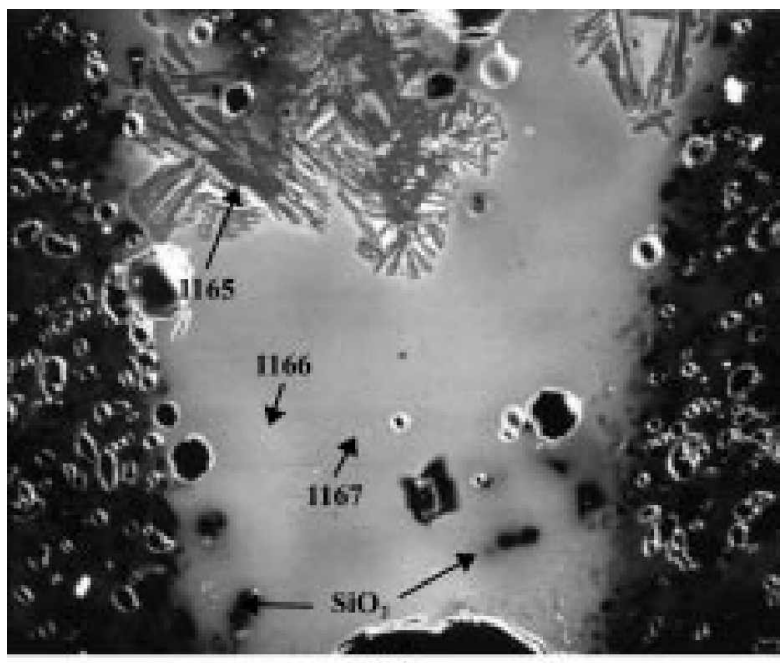

(b)

Fiyure 8. Backscattered clectron images of black inlav. (a) 169 (S-27-9) (b) A higher magnification of the boxed area in (a).

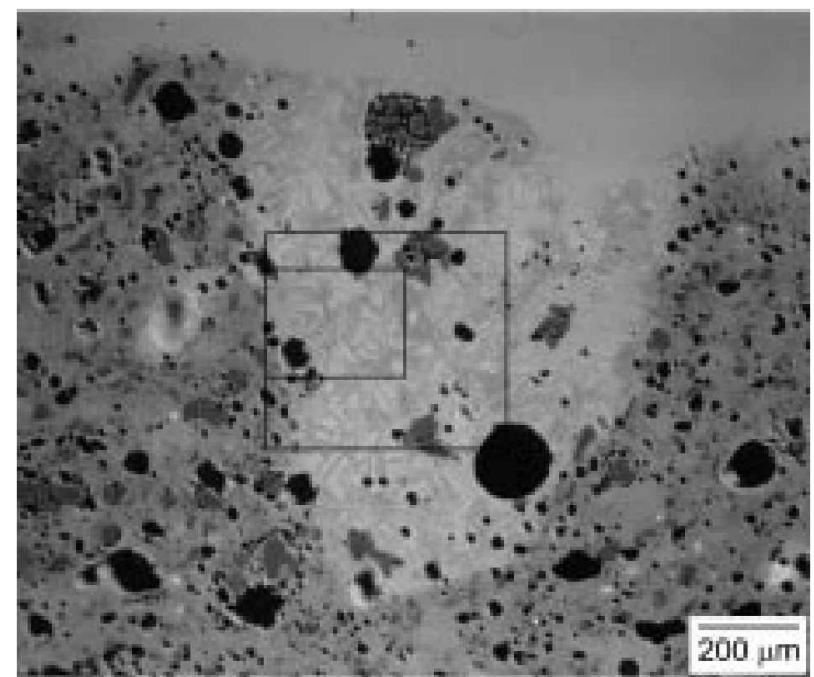

(a)

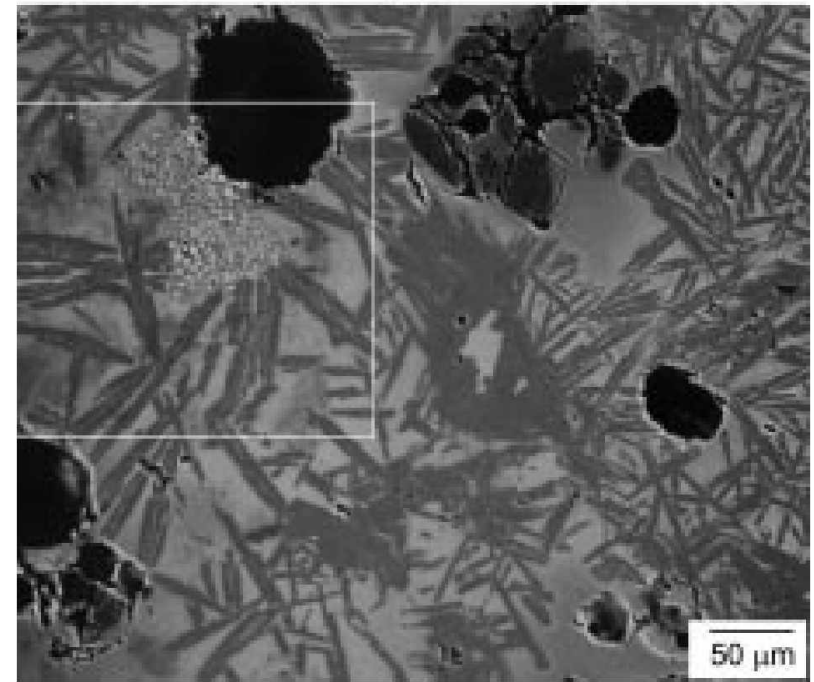

(b)

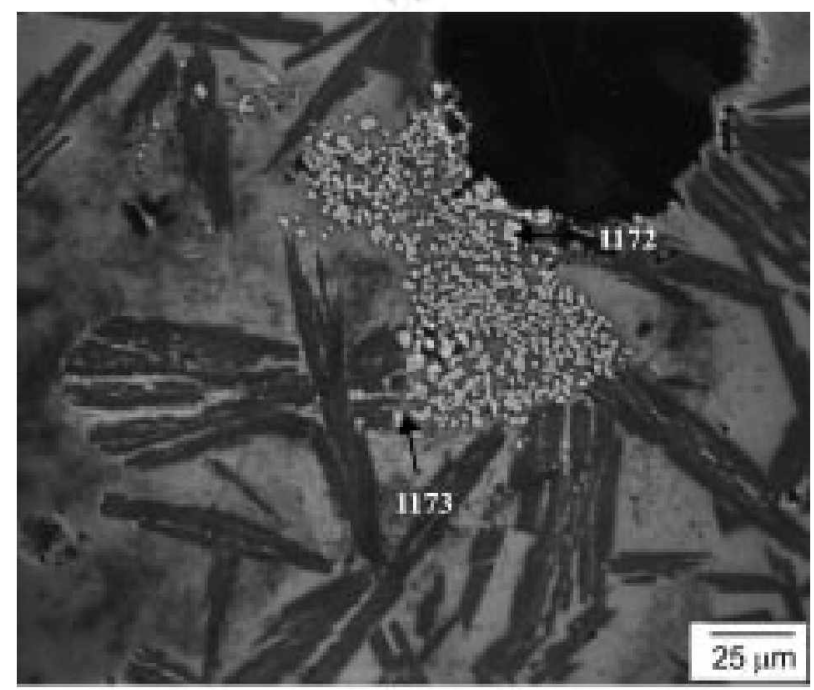

(c)

Figure 9. Backscalterol electron images of line crsstals in black inlay of 22 (CELI-3). (a) Black inlay in relation to olacs and hody; (b) A higher masnification of the area indicated by larger rectangle: (c) $A$ higher masnification of the area indicated by the smaller rectangle 
content of aluminum oxide. between 30 to +0 wt. \% compared with about 20 w1.\% in the body matcrial. Muscovite mineral grains. such as 1157 and 1158 . are presen ed in near-original composition (Table 1 ) in the less vitrificd sample in Figure 6(c) and are partially responsible for the higher clay content in inlay matcrial.

Potters speedy action of the filling often left some areas only sparscly filled or exen empty like the dark left edge in Figure 6(a). The glaze seeped through some of these empty or sparscly filled spaces. crealing "intergrade" sections of the white areas of similar appearance as the glaze in more vilrified samples. Only one such area is developed in the iniddle of inlay in Figure 6(a). bul several places. including the backside. are devcloped in Figure 6(b). In Table 1 the comparison of EPMA measurements reveals the intermediate mature of intergrade composition between the glaze and regular areas of white inlay. As shown by the thread-like lines in Figures 6(a) and 6(b). these intergrades are usually cracked during the cooling process due to the mismatch in the expansion coeflicients of the surrounding materials. Also the intergrade area often leads to cracks in the glaze. as is the casc in Figure 6(a).

In the threc sets of two pictures each in Figure 7. microcrystals are shown both in the overall relation to gla $x$ c (a-l. b-1. c-1) and more focused in higher magnification (a-2, b-2. c-2). Necdles of calcium feldspar anorllite are devilrificd extensively in the interface between the Ca-rich glase and Al-rich white inlay as was the case beiween the glaye and body. The necdle shapes are gathered delicatcly like flowers in Figure 7(a-2). massively aggregated in Figure 7(b-2), and occur in individual rod forms in Figure 7(c-2). The clusier of white grains in Figures 7(c-1) and 7(c-2) (1 185 in Table 1$)$ in the backside intergrade is a mineral of apatite composition $\left[\mathrm{Ca}\left(\mathrm{PO}_{1}\right) \mathrm{O}_{3}(\mathrm{OH}, \mathrm{F} . \mathrm{Cl})\right]$. This $\mathrm{Ca}$ and phosphate mincral is likely to occur in wood ash, a main component of ccladon glarc. but it is rarely as well presenced in Kory celadon. as shown here.

Black Inlay. In backscattered cleciron images of Figures 8 and 9 lhe black inlay appears very similar to the glaze. There is lardly any interface between the glaze and the inlay in Figure 8(a). This cont rasts strikingly with white inlay, which was much less vitrificd than either the glaze or body. The difference is maturally due to the compositions of two types of inlay. Compared with white inlay. typical matrix spots as 1166 and 1167 in Figure 8(b) of black inlay have a mucl lower content of aluminum oxide. around $20 \mathrm{w1. \%}$. mucl ligher content of iron oxide. around 12 wt.\%. and higher content of calcium. above 5 wt.\% (Table 1). Phospliorous and manganese oxides. Found in the ash component of glaze. are also present in black inlay. Similarity between glaze and black inlay in composition and microstructure suggests that black inlay was formulated by adding a black clay component. sucli as biotitc. lo glare material.

The incision for the black inlay in Figure 8(a) is so decp that its lip is understandably left cmply and appears black in the backscattered clectron image. Higher magnificd image in Figure 8(b) shows the same microstructural features in the inlay as in the glaze. Aggregates of tiny quart\% grains are found in areas ever so slightly darker than the ayerage matrix. As in glaze the darker areas represent quart/-feldspar intergrowth, whose feldspar portion has melted but not yct vitrified and mixed completely into matrix.

As was expected from the appearance of necdle shapes. 1165 spot is high in calcium and in aluminum. showing that it is anorthite crystal (Table 1). This mineral occurs as commonly in black inlay as in glaze. In fact. it is devitrificd in such abundance in inlay shown in Figure 9 that cren in smaller magnification in Figure 9(a) cry stal necdles are secn all over the inlay. The cluster of white grains in Figures 9(b) and $9(\mathrm{c})$ has spincl compositions of $\mathrm{MgO}-\mathrm{Fc}_{2} \mathrm{O}_{3}$. Rather abundant occurrence of sucl spincl grains is an interesting characteristic feature of the black inlay used in the Kangjin ccladons.

\section{Conclusion}

The body images of two irregularly mixed matrix phases are similar to those in the Chinese celadons from Jingderhen. ${ }^{1-4}$ The mixiure of muscovite clay component and feldspars in tow wh. the tammi material of the inlaid celadon. is reflected in sucl images.

Images of glaze include bubbles of various sizes. remunt muscovite mincrals. quart/ minerals cracked around the rims. composite minerals of quartzite grains in the mist of melted feldspar. and devitrified anorthite crystals. These and the schlicren effect from the inhomogencous mixing of the glaze matcrial are responsible for the decp translucent soft appearance of gla $\%$.

The incised areas of white and black inlay are often left cmply or only sparsely filled. In white inlay. glaze secped through some of these arcas forming intergrade of internediate composition betwecn the white inlay and the glaze. Necdle-sliaped anorthite crystals are formed in the interface betwecn the inlay and the glaze and also in intergrade areas. The high content of aluminum. above 35 wt.\%. and remmant muscovite mincrals suggest $t e x u k$ as an important component for the inlay as it is for the body: Kaolinite type clay with only a small amount of iron impurity might have been added to the tost $k$ body material.

The close similarity in the microstructural features between the black inlay and glaze suggests that glaze was used together with biotite clay that contains much iron oxide as the inlay material. Extensive amounts of anorthite and the aggregates of spinel grains of $\mathrm{MgO}-\mathrm{Fe}_{2} \mathrm{O}_{\mathrm{i}}$ composition are found in the inlay.

As seen in this work backscattered electron images and the EPMA compositional measurement of distinct micro-areas lead to important information about the production techuical parameters. This is one of several reports on many images and detailed descriptions that the authors are preparing from several hundreds of optical and electron microscopic images and micro-compositional measurements taken on Korean traditional ceramics. Such a systematic presentation is expected to reveal much about not only Korean ceramics. but also 
Their developmental relationship with Chinese and Japanese technology:

Acknow ledgement. We would like to thank David Lange of Hoffman Gcological Laboralon at Hanard University for making microstructural identification and EPMA compositional measurements. We would also like to acknowledge with gratilude the excavation tcam from Hacgang Ceramics Museum. especially Mr. Kun Choi. for providing us the shards excavaled in Kangiin.

\section{References}

1. Kingery. W. D. Commies and C'milization: Kingery. W. D.. Ed.: American Ceramic Sociely: Westerville. Ohio. U.S.A. 1986: Vol. 3. $\mathrm{p} 153$.

2. I Jangst. K. ('elatom Iawes of the Kono Perod, 918-1302: ChoiBac, S. Ed: Museum fùr Ostiatisehe Kunst: Cologne Germany: $1984: p 233$

3. Vandiver. P. B.: Corl. L. A.: Handwerker. C. Coramics and Civilization: Nolis. M. D. Ed.: American Ceramic Sociely: Weslerville. Ohio. U. S. A.. 1989: Vol. 4. p 347.

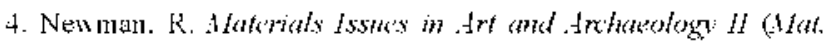

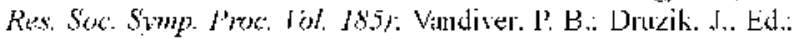
Materials Research Sociely: L'illsburgl. P'ennsỵlvania. U. S. A. I99I: $\mathrm{p}+29$.

5. Koll Choo. C. K. Waterials Issues in int and Ltrhatology II Mat Res Soc. Symp. Proc. Iol 267). Vandifer. P. B. at al. Fds.: Materials Research Sociely; P'illsburgh. P'ennsylvania. U. S. A. 1992: 033 .

6. Kol. K. J. Son an Hisf of Sci. Soc. 1992. H. 23.

7. Koh Choo, C. K. Lrchaeonetry 1995. 37. 53.

8. Koh Cho. C. K.: Kim, S.: Kang, II. T.: Do. I. Y.: I.ce, Y. F.: Kim, G. II. Archaeonetry 1999. 11,51 .

9. Lee. Y. E.: Koh. K. J. Nonem Chem. Soc. 1998. 42. 251.

10. Koh Choo. C. K.: Kim. K. H.: Lee. Y. E.: Kim. J. S. Awhomemetm 2002. 4t. 199 .

11. Iee, Y. Г..: Koh, K. J. Korean (hem. Soc. 2002. f6. 125.

12. T'ac-p'ing I ao-jên (Song dinasty). Hsti-chung-chin in Hsüch-hat lei-pien by Ts'ao Jung (1613-1685). printed in 1831 (in Chinese).

13. Vandiver. P. B. The Radiance of Jade and the Clarity of WatherSoram Ceramics from the Araka Collection-: Itoll. I.: Mino. Y.. Organized: The Art Institute ol Chicago: Hudson Hills Press: Neu York, U. S. A.. 1991:p 151.

14. Titc, M. S.: Frestonc, I. C.: Bimson. M. Arohoemetm 1984. 26. 1.39 